\title{
ETNOMATEMATIKA PASURUAN: EKSPLORASI GEOMETRI UNTUK SEKOLAH DASAR PADA MOTIF BATIK PASEDAHAN SUROPATI
}

\author{
Bakhrul Ulum ${ }^{1}$, Mega Teguh Budiarto ${ }^{2}$, Rooselyna Ekawati ${ }^{3}$ \\ ${ }^{1}$ Mahasiswa Program Pascasarjana, Prodi Pendidikan Dasar, Universitas Negeri Surabaya, \\ ${ }^{2 \& 3}$ Dosen Pascasarjana, Prodi Pendidikan dasar, Universitas Negeri Surabaya \\ e-mail: 'bakhrululum40@gmail.com
}

\section{Received : $\quad$ Maret 2018}

Reviewed: April 2018

Accepted : $\quad$ Mei 2018

Published : $\quad$ Mei 2018
ABSTRACT

This research aims to explore and describe the ethnomathematics on Pasuruan society from the concept of geometry for elementary school on the Pasedahan Suropati batik motive, the philosophical meaning of it, and the alternative usage in teaching geometry in primary school. This research is a qualitative research with ethnographic approach, in wich the technique of collecting a literature study, observation, interviews, fields note, and documentation. Based on the data collecting, there are 6 kinds of Pasedahan Suropati batik in Pasuruan, they are Suruh Leaves motive, Podang Bird motive, Harmoni Built motive, Tembikar motive, Phoniex Bird motive, and Mangrove motive. The meaning of Pasedahan Suropati batik philosophically is Untung Suropati is very wise person, so people who wear this Pasedahan Suropati batik is expected has a wise attitude Untung Suropati. The concept of geometry of elementary school on Pasedahan Suropati batik motive is the concept of point, straight lines, curved lines, zig-zag lines, high lines, parallel lines, angels, triangle, rectangle, oval, and fold symmetry. Thus, the geometry concept of Pasedahan Suropati batik motive in elementary school, can be used in learning geometry such as the introduction of line, the introduction of the angle, and the introduction of shape.

Keywords: Ethnomathematics, geometry, Pasedahan Suropati batik.

\section{ABSTRAK}

Penelitian ini bertujuan untuk menggali dan mendeskripsikan etnomatematika yang ada pada masyarakat Kota Pasuruan yang dilihat dari konsep geometri untuk sekolah dasar yang terdapat pada motif batik Pasedahan Suropati, makna filosofis yang terkandung di dalamnya, serta alternatif penggunaannya dalam pembelajaran geometri di sekolah dasar. Penelitian ini merupakan penelitian kualitatif dengan pendekatan etnografi, yang mana teknik pengumpulan datanya dilakukan dengan cara studi kepustakaan, observasi, wawancara, catatan lapangan, dan dokumentasi. Berdasarkan hasil pengumpulan data penelitian diperoleh 6 jenis motif batik Pasedahan Suropati yang ada di Kota Pasuruan, yaitu motif Daun Suruh, motf Burung Podang, motif Gedung Harmoni, motif Tembikar, motif Burung Phoenix, dan motif Mangrove. Secara filosofis batik Pasedahan Suropati memiliki makna bahwa Untung Suropati adalah orang yang sangat bijaksana, jadinya orang yang memakai batik Pasedahan Suropati diharapkan memiliki sifat bijaksana laksana Untung Suropati. Konsep geometri untuk sekolah dasar yang ada pada motif batik Pasedahan Suropati adalah konsep titik, garis lurus, garis lengkung, garis zig-zag, garis tinggi, garis sejajar, sudut, segitiga, persegipanjang, oval, dan simetri lipat. Dengan demiian, motif batik Pasedahan Suropati yang memiliki konsep geometri untuk sekolah dasar, tentunya dapat digunakan dalam pembelejaran geometri seperti pada pengenalan garis, pengenalan sudut, dan pengenalan bangun datar sederhana.

Kata Kunci: Etnomatematika, geometri, batik Pasedahan Suropati. 


\section{PENDAHULUAN}

Pendidikan dan kebudayaan merupakan bagian yang tidak dapat dipisahkan, laksana dua sisi mata uang, keduanya saling mendukung dan menguatkan. Kebudayaan menjadi dasar falsafah pendidikan, sementara pendidikan menjadi penjaga utama kebudayan, karena peran pendidikan adalah membentuk orang untuk berbudaya. Tepatlah jika Ki Hajar Dewantara dalam Wibowo dan Gunawan (2015: 13) mengibaratkan pendidikan yanpa kebudayaan, seperti perahu di lautan tanpa panduan arah. Sejalan dengan hal itu, Budiarto (2016: 2), juga mengungkapkan bahwa pendidikan dan budaya adalah sesuatu yang tidak bisa dihindari dalam kehidupan sehaihari, karena budaya merupakan kesatuan yang utuh, menyeluruh, dan berlaku dalam suatu masyarakat, serta pendidikan merupakan kebutuhan mendasar bagi setiap individu dalam masyarakat. Pendidikan dan budaya memiliki peran yang sangat penting dalam menumbuhkembangkan nilai-nilai bangsa yang berdampak pada pembentukan karakter yang didasarkan pada nilai budaya yang luhur.

Pada tahun 2013, dunia pendidikan di Indonesia mengalami perubahan kurikulum, yang semula dari Kurikulum Tingkat Satuan Pendidikan (KTSP) menjadi Kurikulum 2013 (K-13). Ada yang menarik dari kurikulum yang baru ini, pada tingkat sekolah dasar (SD) materi pembelajaran tidak lagi diajarkan secara parsial, akan tetapi diajarkan secara tematik integratif. Selain itu, hampir semua materi pembelajaran dikaitkan dengan budaya yang ada di negeri ini, sebagaimana pendapat Fitroh dan Hikmawati (2015: 334) yang menyatakan bahwa K-13 menonjolkan peningkatan kemampuan siswa terhadap budaya.
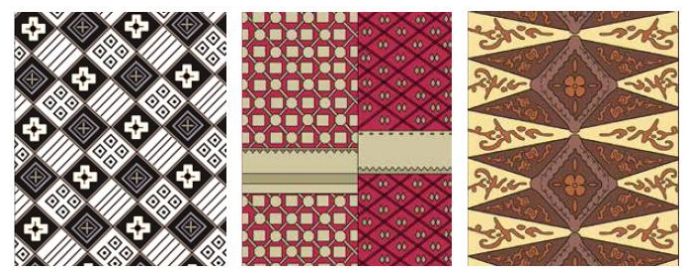

\section{Gambar 1.}

Kain Tradisonal Nusantara

Sumber: Kementerian Pendidikan dan Kebudayaan

Republik Indonesia, 2016: 48.

Gambar di atas merupakan salah satu contoh penerapan nilai-nilai budaya dalam pembelajaran K-13 yang ada pada kelas IV Tema 1 "Indahnya Kebersamaan", Subtema 1 "Indahnya Kebersamaan", pembelajaran ke-4.
Kain tradisional nusantara tersebut digunakan sebagai bagian dari muatan pembelajaran matematika, yaitu pada materi segibanyak. Di mana dengan pemanfaatan gambar tersebut, siswa diminta untuk menemukan segibanyak, baik segibanyak beraturan maupun segibanyak tidak beraturan.

Ketika budaya, matematika, dan pendidikan dikombinasikan seperti pembelajaran segibanyak tersebut, maka percampuran tersebut sering kali dinamakan ethnomathematics (Walle. 2008: 104). Etnomatematika merupakan matematika yang dipraktikkan oleh kelompok budaya seperti masyarakat perkotaan dan pedesaan, kelompok buruh, anak-anak dari kelompok usia tertentu, masyarakat lainnya (D'Ambrioso dalam Budiarto, 2015: 2). Sebagai contoh hasil kajian etnomatematika dari Liphka dan Andrew-Irkhe (2009) yang mengkaji konsep geometri pada budaya Yup'ik Dora di Alaska. Dalam hal ini konsep geometri dikaji pada artefak Yup'ik, pola yang menghiasi pakain Eskimo Yos-yos, serta pakaian yang lainnya, seperti pada gambar berikut ini:
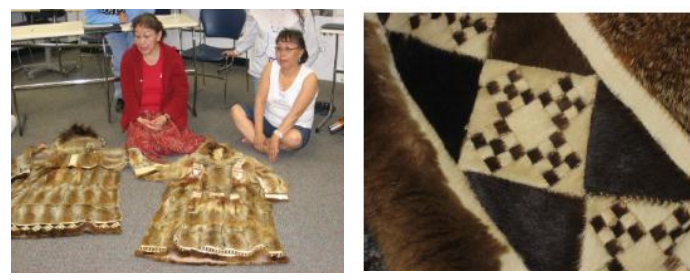

Gambar 2

Motif Pakaian Budaya Yup'ik Dora

Sumber: Lipka dan Andrew-Irkhe, 2009: 8

Indonesia yang memiliki semboyan Bhineka Tunggal Ika, tentunya memiliki keberagaman budaya yang sangat bervariasi, mulai dari kesenian, bentuk bangunan, pakaian, ukiran, batik, dan lain sebagainya. Dengan demikian, tidak dapat dipungkiri kalau konsep matematika, khususnya geometri juga sudah diterapkan dalam budaya yang ada di negeri ini. Sebagai contoh pada motif batik kawung, sebuah motif yag memiliki bentuk geometris dengan perpaduan bulatan kecil dan besar, sebagaimana gambar berikut:

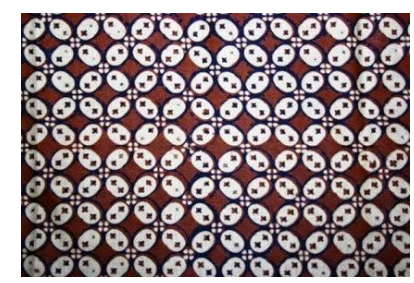


Gambar 3

Motif Batik Kawung

Sumber: Wulandari, 2011: 135

Kekeyaan budaya bangsa Indonesia memang tiada banding, termasuk budaya batik. Corak batik atau yang sering disebut juga motif batik yang berkembang di berbagai daerah di Indonesia sangat beragam. Masingmasing daerah memiliki motif batik yang unik dan khas. Hal ini dikarenakan motif batik mencerminkan filosofi dan budaya masyarakat tempat batik itu berasal. Sebagaimana batik Kota Pasuruan.

Batik Kota Pasuruan atau yang dikenal dengan batik Pasedahan Suropati memiliki motif khas Daun Suruh sebagai motif utama serta dipadukan dengan motif-motif yang lainnya, seperti motif Burung Podang, Kawung, Truntum, dan lain sebagainya. Motif Daun Suruh secara filosofis memiliki makna bahwa asal-usul kata Pasuruan berasal dari kata $P a-s u r u h-a n$, yang bermakna daun suruh (sirih), sedangkan nama Pasedahan Suropati sendiri memiliki makna bahwa sejarah Kota Pasuruan tidak bisa dilepaskan dari cerita Untung Suropati. Untung Suropati merupakan pahlawan nasional yang arif dan bijaksana yang pernah memerintah Kota Pasuruan, bahkan di Kota Pasuruan sendiri terdapat sebuah petilasan Untung Suropati yang terdapat di Dusun Mancilan, Kelurahan Pohjentrek, Kecamatan Purworejo. Harapannya adalah siapa saja yang memakai batik Pasedahan Suropati memiliki hati yang bijaksana sebagaimana Untung Suropati.

Batik Kota Pasuruan memang belum seterkenal batikbatik dari daerah lain, seperti Yogyakarta, Solo, Pekalongan, atau Madura. Batik Kota Pasuruan baru ada pada tahun 2003, ketika Pemerintah Kota Pasuruan mengadakan lomba desain batik khas daerah. Akan tetapi, dari tahun 2003 hingga sekarang perkembangan batik Pasedahan Suroapti tumbuh dengan pesat, karena sudah ada dua generasi yang mengembangkan batik Pasedahan Suropati, bahkan sudah memperoleh hak cipta dari Direktorat Hak Cipta dan Desain Industri, Direktorat Jenderal Hak Kekayaan Intelektual pada tanggal 3 Agustus 2005 dengan nomor 027811.

Melihat potensi Kota Pasuruan yang memiliki batik khas yang diwariskan dari generasi ke generasi, hingga generasi kedua sekarang, ditambah dengan kajian etnomatematika yang mengeksplorasi konsep geometri sebelumnya, maka peneliti tertarik untuk meneliti tentang "Etnomatematika Kota Pasuruan: Eksplorasi Geometri Untuk Sekolah Dasar Pada Motif Batik Pasedahan Suropati", dengan tujuan untuk: (1) mendeskripsikan konsep geometri untuk sekolah dasar yang ada pada motif batik Pasedahan Suropati, (2) mengetahui makna filosofis yang terkandung pada motif batik Pasedahan Suropati, serta (3) mengetahu alternatif penggunaan motif batik Pasedahan Suropati dalam pembelajaran geometri di sekolah dasar.

\section{TINJAUAN PUSTAKA}

\section{A. Etnomatematika}

Istilah etnomatematika pertama kali dikemukakan oleh Ubiratan D'Ambrioso seorang matematikawan dan guru matematika Brazil pada tahun 1977. Istilah etnomatematika pertama kali diperkenalkan D'Ambrioso sebagai metodologi untuk melacak dan menganalisis proses produksi, pemindahan, penyebaran, dan pelembagaan (matematika) dalam berbagai macam sistem budaya, yang mana D'Ambrioso membedakan matematika menjadi matematika akademik yang diajarkan di sekolah, serta etnomatematika yang digambarkan sebagai matematika yang dipraktikkan di antara kelompok budaya yang dapat diidentifikasi, seperti masyarakat, suku, kelompok buruh, anak-anak dari kelompok tertentu dan kelas profesional (Prabawati, 2016: 27).

Secara bahasa etnomatematika berasal dari awalan ethno, kata dasar mathema, dan akhiran tics. Ethno diartikan sebagai sesuatu yang sangat luas yang mengacu pada konteks sosial budaya, termasuk bahasa, jargon, kode, perilaku, mitos, dan simbol. Sedangan, mathema memiliki arti menjelaskan, mengetahui, memahami dan melakukan kegiatan sepertu pengodean, mengukur, mengklasifikasikan, dan menyimpulkan. Serta, akhiran tics berasal dari kata techne yang memiliki makna sama dengan teknik (D'Ambrioso dalam Rosa dan Orey, 2011: 35). Lebih lanjut, Orey dan Rosa (2006: 62) menyatakan bahwa esensi dari studi etnomatematika adalah mempelajari budaya antropologi (etnografi), pemodelan matematika, dan matematika itu sendiri. Irisan dari komponenkomponen matematika, pemodelan matematika, dan etnografi inilah yang disebut sebagai etnomatematika, yang mana hubungan ketiganya dapat digambarkan sebagai berikut:

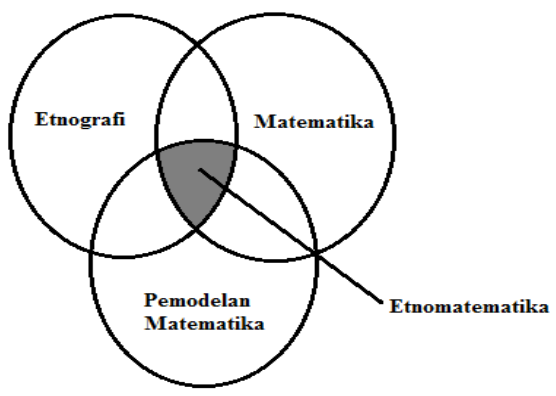


Gambar 4

Etnomatematika

Sumber: Orey dan Rosa, 2006: 62

\section{B. Konsep Geometri Untuk Sekolah Dasar}

Matematika merupakan salah satu mata pelajaran yang diberikan pada jenjang sekolah dasar (SD). Dalam Silabus SD/MI Tematik Terpadu yang diterbitkan Kementerian Pendidikan dan Kebudayaan Republik Indonesia pada tahun 2016, matematika SD diajarkan dalam 3 ruang lingkup, di antaranya: (1) bilangan (bilangan cacah, bulat, prima, pecahan, kelipatan dan faktor, pangkat dan akar sederhana); (2) statistika (menyajikan dan menafsirkan data tunggal) dalam kehidupan sehari-hari); serta (3) geometri dan pengukuran (bangun datar dan bangun ruang, hubungan antar garis, pengukuran (berat, panjang, luas, volume, sudut, waktu, kecepatan dan debit, letak dan koordinat suatu benda)).

Geometri merupakan cabang matematika yang tidak mengutamakan hubungan antar bilangan, meskipun di dalamnya terdapat suatu bilangan, akan tetapi geometri mempelajari hubungan antara titik, garis, sudut, bidang, serta bangun datar dan bangun ruang (Susanah dan Hartono, 2014: 1). Ada dua macam geometri yang dipelajari di SD, yaitu geometri datar dan geometri ruang. Geometri datar merupakan bentuk geometris yang hanya terdiri dari dua dimensi (panjang dan lebar), atau hanya memiliki luas tetapi tidak memiliki volum, sedangkan geometri ruang merupakan bentuk geometris tiga dimensi (panjang, lebar, dan tinggi) atau yang memiliki volum. Adapun secara garis besar, konsep geometri yang dipelajari di SD dapat dikelompokkan pada tabel berikut ini:

Tabel 1. Geometri Untuk SD

\begin{tabular}{|c|c|}
\hline Kelas & Konsep Geometri \\
\hline I & $\begin{array}{l}\text { Garis (garis lurus, garis lengkung, garis zig- } \\
\text { zag), bangun datar (persegi, persegipanjang, } \\
\text { segitiga, lingkaran), bangun ruang (kubus, } \\
\text { balok, kerucut, bola). }\end{array}$ \\
\hline II & $\begin{array}{l}\text { Garis (garis lurus, sinar garis, ruas garis), } \\
\text { sudut, bangun datar (segiempat, segitiga, } \\
\text { segienam), bangun ruang (kubus), serta } \\
\text { membedakan bangun ruang dan bangun datar. }\end{array}$ \\
\hline III & $\begin{array}{l}\text { Bangun datar } 4 \text { sisi dan bukan } 4 \text { sisi, bangun } \\
\text { datar (persegi, persegipanjang, segitiga, } \\
\text { layang-layang, trapesium, belahketupat), } \\
\text { simetri lipat dan simetri putar). }\end{array}$ \\
\hline IV & $\begin{array}{l}\text { Garis (sejajar dan berpotongan), sudut } \\
\text { (sehadap dan bersebrangan), bangun datar } \\
\text { (persegi, persegipanjang, segiitga, trapesium, } \\
\text { belahketupat, jajargenjang, layang-layang), } \\
\text { segibanyak, pengubinan, dan pencerminan. }\end{array}$ \\
\hline
\end{tabular}

\begin{tabular}{|c|c|}
\hline Kelas & Konsep Geometri \\
\hline V & $\begin{array}{l}\text { Garis, sudut, bangun datar (lingkaran), bangun } \\
\text { ruang (kubus dan balok). }\end{array}$ \\
\hline VI & $\begin{array}{l}\text { Sudut (lancip, tumpul, siku-siku, ber- } \\
\text { sebrangan, sudut dalam segitiga), bangun } \\
\text { datar (lingkaran), poligon (beraturan, tidak } \\
\text { beraturan, convex, concave), simetri lipat dan } \\
\text { simetri putar, bangun ruang (kubus, balok, } \\
\text { limas segiempat, tabung, kerucut). }\end{array}$ \\
\hline
\end{tabular}

\section{Batik Pasedahan Suropati}

Pada tanggal 2 Oktober 2009 UNESCO sebagai lembaga PBB untuk kebudayaan, ilmu pengetahuan, dan pendidikan telah menetapkan batik sebagai warisan budaya dunia yang dihasilkan oleh negara Indonesia. Batik Indonesia dipandang sebagai warisan kemanusiaan untuk budaya lisan dan nonbendawi, dan sejak itulah tanggal 2 Oktober diperingati sebagai hari batik di Indonesia. Secara etimologi, kata batik berasal dari bahasa Jawa, amba yang berarti lebar, luas, kain; dan titik yang berarti titik atau matik (kata kerja membuat titik), yang kemudian berkembang menjadi istilah batik, yang berarti menghubungkan titik-titik menjadi gambar tertentu pada kain yang luas dan lebar. Selain itu, dalam bahasa Jawa, batik ditulis dengan bathik, yang mengacu pada huruf jawa tha, yang menunjukkan bahwa batik adalah rangkaian dari titik-titik yang membentuk gambar tertentu (Wulandari, 2011: 4).

Batik Pasedahan Suropati, bisa dibilang msih tertinggal dengan batik dari daerah-daerah yang lain, karena batik Pasedahan Suropati baru ada pada tahun 2003, yaitu ketika diadakannya lomba desain motif batik khas daerah yang diselenggarakan oleh Pemerintah Kota Pasuruan. Pada perkembangannya, setelah dari lomba tersebut, hingga sekarang sudah terdapat dua generasi pengrajin batik Pasedahan Suropati. Serta, pada tanggal 3 Agustus 2005, batik Pasedahan Suropati telah memperoleh hak cipta dari Direktorat Hak Cipta dan Desain Industri, Direktorat Jenderal Hak Kekayaan dan Intelektual dengan nomor 027811 dengan Pemerintah Kota Pasuruan sebagai pemegang hak cipta. Sebagai pemegang hak cipta atas batik Pasedahan Suropati, Pemerintah Kota Pasuruan menggunakan batik Pasedahan Suropati sebagai pakaian dinas pegawai di lingkungan Pemerintah Kota Pasuruan dan seragam sekolah bagi siswa SD dan SMP guna sebagai wujud pelestarian budaya yang dimiliki.

Sejalan dengan perkembangan waktu, motif-motif baru dihasilkan oleh para pengrajin, yang mana motif tersebut tidak bisa dilepaskan dari yang namanya motif Daun Suruh, karena mengingat asal-usul nama Pasuruan berasal dari kata suruh. Motif Daun Suruh inilah yang kemudian dikombinasikan dengan motif-motif yang 
lainnya, seperti motif Tembikar, motif Burung Phoenix, serta motif nasional (motif Kawung dan Truntum).
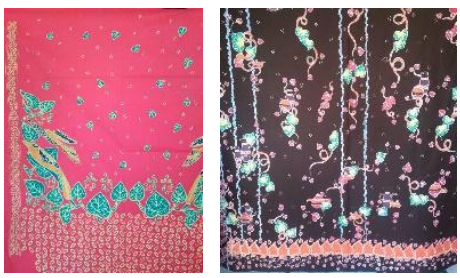

Gambar 5

Motif Batik Pasedahan Suropati Sumber: Batik Tulis Kali Gembong

\section{Konsep Pembelajaran Matematika dengan Etnomatematika}

Pembelajaran matematika dengan pendekatan etnomatematika dalam kurikulum sekolah bukanlah hal yang baru. Dengan memasukkan etnomatematika dalam kurikulum sekolah akan memberikan nuansa baru dalam pembelajaran matematika di sekolah dengan pertimbangan bahwa setiap daerah terdiri atas berbagai macam suku dan budaya, serta setiap suku memiliki cara tersendiri dalam menyelesaikan masalah yang dihadapinya.

Pemanfaatan budaya dalam pembelajaran matematika bukanlah digunakan sebagai motivasi atau sebagai pengantar, melainkan sebagai bagian dari memahami bagaimana ide matematika dikembangkan dan bagaimana mereka dibangun ke dalam sistem, dirumuskan, dan diterapkan dalam berbagai cara dalam budaya. Dengan kata lain, budaya tersebut digunakan sebagai sumber belajar (Rosa dan Orey, 2011).

Menurut Rowland dan Carson dalam Budiarto (2015: 5) penerapan etnomatematika dalam pembelajaran di sekolah, memiliki peranan yang relatif sama dengan matematika formal, yaitu sebagai (1) pengganti matematika sekolah; (2) penyuplai matematika sekolah; (2) batu loncatan ke matematika sekolah; dan (4) motivasi untuk matematika sekolah. Dengan demikian, pembelajaran matematika dengan pendekatan etnomatematika merupakan salah satu cara yang dipersepsikan dapat menjadikan pembelajaran matematika yang bermakna dan kontekstual yang sangat terkait dengan komunitas budaya, di mana matematika dipelajari dan diterapkan selaras dengan komunitas budaya tersebut, serta pembelajaran matematika menarik dan menyenangkan. Kondisi belajar yang seperti ini memungkinkan terjadinya penciptaan makna kontekstual berdasarkan pada pengalaman sebagai seorang anggota suatu masyarakat budaya tersebut. Sebagaimana hasil penelitian yang dilakukan oleh Massarwe, Verner, dan Bshouty (2013) yang memanfaatkan ornamen pada budaya Israel untuk menganalisis geometri, menunjukkan bahwa pemanfaatan ornamen dalam pembelajaran geometri $90 \%$ membantu siswa untuk memahami konsep-konsep geometri, 88,6\% membantu dalam mengungkap sifat geometris, dan $80,0 \%$ dalam pembuktian.

\section{METODE}

Penelitian ini merupakan penelitian kualitatif dengan pendekatan etnografi. Pendekatan penelitian etnografi merupakan suatu kegiatan yang mendeskripsikan tentang suatu kebudayaan, yang mana tujuan utamanya adalah untuk memahami suatu pandangan hidup dari sudut pandang penduduk asli. Sebagaimana yang dikemukakan oleh Malinowski (dalam Spradley, 1997: 3), tujuan dari etnografi adalah memahami sudut pandang penduduk asli, hubungannya dengan kehidupan, serta untuk mendapatkan pandangannya mengenai dunianya. Sedangkan penelitian kualitatif, peneliti gunakan karena peneliti ingin terlibat secara langsung di lapangan, mencatat secara hati-hati apa yang terjadi, melakukan analisis reflektif terhadap dokumen yang ditemukan di lapangan, dan membuat laporan secara lengkap dan terperinci.

Dalam penelitian kualitatif dengan pendekatan etnografi yang menjadi instrumen penelitian adalah peneliti sendiri (human instrument), yang mana peneliti sebagai instrumen utama yang tidak bisa digantikan oleh orang lain. Sebagai instrumen utama, peneliti berfungsi menetapkan fokus penelitian, memilih informan sebagai sumber data, melakukan pengumpulan data, menilai kualitas data, menafsirkan data, serta membuat kesimpulan atas temuannya. Selain itu, digunakan juga instrumen pendukung untuk membantu instrumen utama, yaitu berupa pedoman wawancara.

Dalam upaya pengumpulan data penelitian ini dilakukan beberapa tahapan, sebagaimana yang tergambar pada Gambar 6 berikut ini:

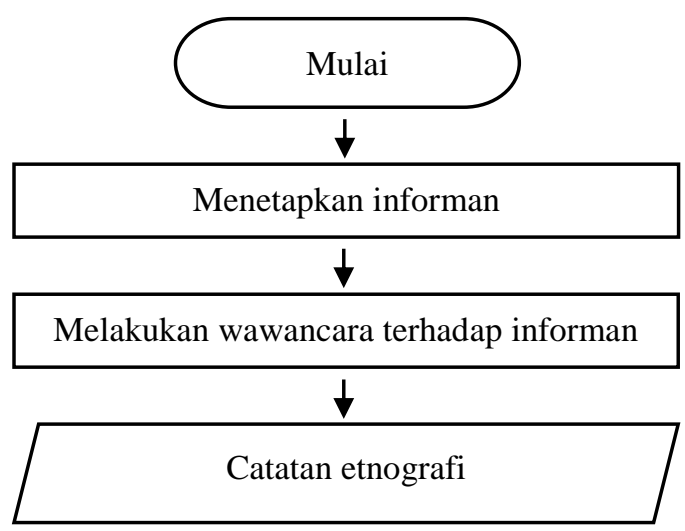




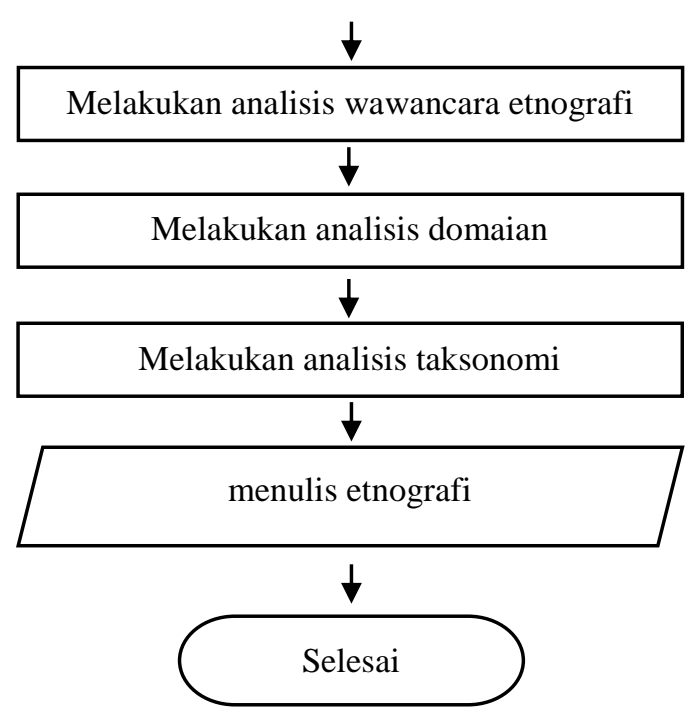

Gambar 6. Prosedur Penelitian

Berdasarkan Gambar 6 tesebut, lebih lanjut dapat dijelaskan sebagai berikut:

1. Menentukan informan. Informan dalam penelitian ini adalah pengrajin batik Pasedahan Suropati yang memahami akan motif batik tersebut, serta dapat bercerita dengan mudah, dan paham akan informasi yang dibutuhkan oleh peneliti.

2. Melakukan wawancara terhadap informan. Dalam penelitian ini, jenis wawancara yang digunakan adalan wawancara semi struktur, yang artinya peneliti memiliki pedoman wawancara dengan beberapa pertanyaan. Namun, pertanyaan tersebut memiliki kemungkinan untuk berkembang.

3. Membuat catatan etnografis merupakan catatan lapangan tertulis yang peneliti peroleh selama di lapangan dari informan, baik catatan hasil observasi, wawancara, serta dokumentasi.

4. Melakukan analisis wawancara etnografis merupakan kegiatan mengubah data yang diperoleh selama di lapangan dengan cara wawancara ke dalam bentuk laporan tertulis (transkrip data). Hal ini dilakukan dengan cara memilah data yang dibutuhkan, serta membuang data yang tidak sesuai dengan dengan kebutuhan.

5. Membuat analisis domain. Analisis domain peneliti lakukan untuk memperoleh gambaran umum dan menyeluruh dari objek yang akan diteliti, dengan cara mengelompokkan atau membuat kategori. Dalam penelitian ini, analisis domain peneliti lakukan untuk mengelompokkan konsep-konsep geometri untuk sekolah dasar yang ada pada motif batik Pasedahan Suropati.
6. Membuat analisis taksonomi merupakan analisis terhadap keseluruhan data yanng terkumpul berdasarkan domain yang ditetapkan. Dengan demikian, domain yang telah ditetapkan menjadi cover term oleh peneliti, serta dapat diuraikan secara lebih rinci dan mendalam melalui analisis taksonomi ini. Dalam hal ini, analisis taksonomi dilakukan dengan cara menjabarkan dan mengelompokkan domaindomain yang telah dilakukan berdasarkan konsep geometri untuk sekolah dasar yang telah ditemukan pada motif batik Pasedahan Suropati, misalnya: konsep garis lurus, persegi, persegi-panjang, lingkaran, dan sebagainya.

7. Menulis etnografi merupakan proses menerjemahkan dan menyampaikan makna-makna yang terkandung dalam suatu budaya ke dalam bentuk tulisan.

\section{HASIL DAN PEMBAHASAN}

Berdasarkan hasil pengumpulan data diperoleh 6 ragam jenis motif batik Pasedahan Suropati, yaitu motif Daun Suruh, motif Burung Podang, motif Gedung Harmoni, motif Tembikar, motif Burung Phoenix, dan motif Mangrove. Dari keenam motif batik Pasedahan

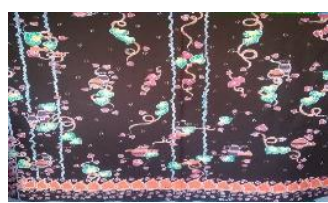
Suropati tersebut, tidak bisa dilepaskan dari motif Daun Suruh. Artinya, semua motif batik Pasedahan Suropati pasti ada motif Daun Suruh yang menghiasi. Hal ini dikarenakan, motif Daun Suruh merupakan ciri khas (icon) dari Kota Pasuruan, yang mana asal-usul kata Pasuruan berasal dari kata $P a$-suruh-an yang berarti daun suruh. hal ini bisa dilihat beberapa motif batik Pasedahan Suropati berikut ini:
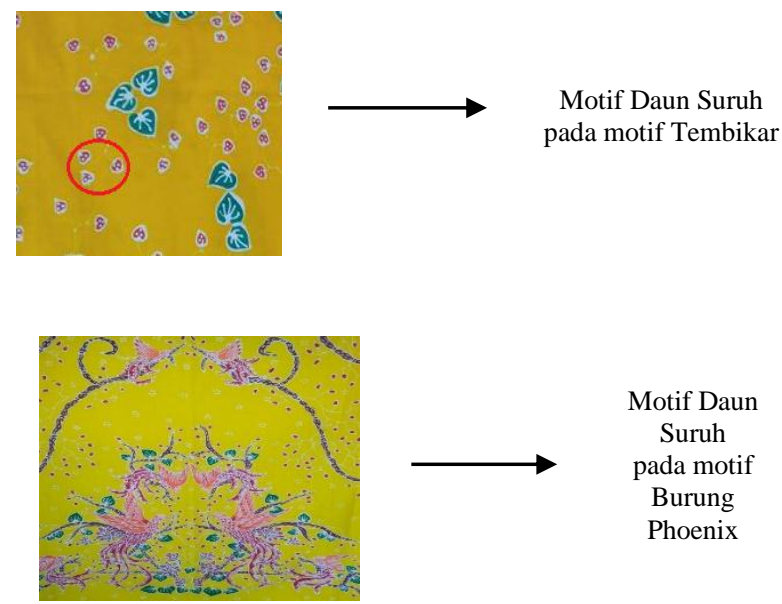

Gambar 7

Motif Daun Suruh pada batik Pasedahan Suropati 
Dari gambar motif batik Pasedahan Suropati tersebut, terlihat bahawa secara umum struktur batik Pasedahan Suropati terdiri atas tiga bagian, yaitu motif utama, motif Daun Suruh (sebagai identitas batik khas Kota Pasuruan), serta motif Pinggiran. motif Pinggiran merupakan motif yang digunakan sebagai hiasan pinggir atau digunakan sebagai pembatas. Motif Pinggirang yang digunakan pada batik Pasedahan Suropati berupa motif nasional, seperti Kawung, Truntum, Parang, dan sebagainya. Selain itu, satu motif batik Pasedahan Suropati terdapat bebrapa warna, misalnya motif Burung Podang yang memiliki warna hijau, merah, dan hitam. Akan tetapi, dengan perbedaan warna ini tidak memengaruhi makna filosofis yang terkandung.

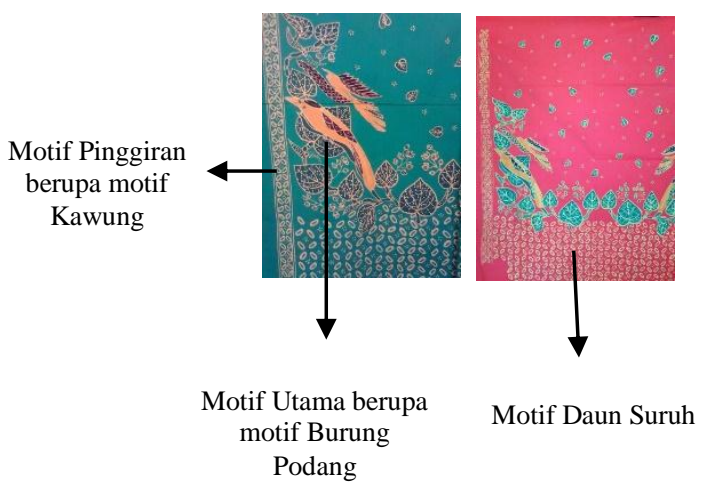

Gambar 8

Struktur Umum Batik Pasedahan Suropati

\section{Konsep Geometri Untuk Sekolah Dasar Pada Motif Batik Pasedahan Suropati}

Berdasarkan pemetaan konsep matematika pada motif batik Pasedahan Suropati menunjukkan bahwa konsepkonsep matematika, khususnya geometri untuk sekolah dasar banyak dijumpai di lingkungan masyarakat atau kebudayaan tertentu, seperti pada motif batik Pasedahan Suropati. Ada beberapa konsep geometri untuk sekolah dasar yang ditemukan pada motif batik Pasedahan Suropati, sebagaimana pada tabel berikut ini:

Tabel 2. Konsep Geometri Untuk Sekolah Dasar Pada motif Batik Pasedahan Suropati

\begin{tabular}{|c|c|c|}
\hline $\begin{array}{c}\text { Konsep } \\
\text { geometri }\end{array}$ & Nama motif & Contoh gambar \\
\hline Titik & $\begin{array}{l}\text { Daun Suruh } \\
\text { Burung Podang } \\
\text { Gedung } \\
\text { Harmoni } \\
\text { Tembikar } \\
\text { Burung Phoenix }\end{array}$ & 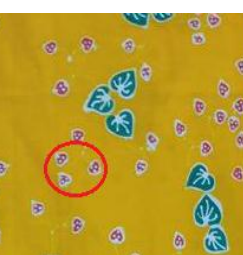 \\
\hline
\end{tabular}

\begin{tabular}{|c|c|c|}
\hline $\begin{array}{l}\text { Konsep } \\
\text { geometri }\end{array}$ & $\begin{array}{l}\text { Nama motif } \\
\text { Mangrove }\end{array}$ & Contoh gambar \\
\hline Garis lurus & $\begin{array}{l}\text { Burung Podang } \\
\text { Gedung } \\
\text { Harmoni } \\
\text { Burung Phoenix }\end{array}$ & \\
\hline $\begin{array}{l}\text { Garis } \\
\text { lengkung }\end{array}$ & $\begin{array}{l}\text { Daun Suruh } \\
\text { Burung Podang } \\
\text { Gedung } \\
\text { Harmoni } \\
\text { Tembikar } \\
\text { Burung Phoenix } \\
\text { Mangrove }\end{array}$ & \\
\hline Garis zig-zag & Burung Phoenix & \\
\hline Garis tinggi & Burung Podang & \\
\hline Garis sejajar & Burung Podang & \\
\hline Sudut & $\begin{array}{l}\text { Daun Suruh } \\
\text { Burung Podang } \\
\text { Gedung } \\
\text { Harmoni } \\
\text { Burung Phoenix }\end{array}$ & \\
\hline Segitiga & $\begin{array}{l}\text { Burung Podang } \\
\text { Gedung } \\
\text { Harmoni }\end{array}$ & \\
\hline $\begin{array}{l}\text { Persegipan- } \\
\text { jang }\end{array}$ & $\begin{array}{l}\text { Gedung } \\
\text { Harmoni }\end{array}$ & \\
\hline
\end{tabular}




\begin{tabular}{|c|c|c|}
\hline $\begin{array}{c}\text { Konsep } \\
\text { geometri }\end{array}$ & Nama motif & Contoh gambar \\
\hline Oval & $\begin{array}{l}\text { Daun Suruh } \\
\text { Burung Phoenix }\end{array}$ & \\
\hline Simetri lipat & $\begin{array}{l}\text { Daun Suruh } \\
\text { Burung Podang } \\
\text { Tembikar } \\
\text { Burung Phoenix }\end{array}$ & \\
\hline
\end{tabular}

\section{Makna Filosofis Motif Batik Pasedahan Suropati}

Batik merupakan salah satu warisan yang sangat istimewa, karena bentuk kain bercorak ini bukan sekedar kain tanpa makna. Di balik setiap motif dan jenisnya, ada berbagai jenis makna filosofis yang memiliki nilai dan sejarah yang panjang. Ada sejarah yang dapat kita baca lewat tuturan corak dan motif batik. Motif dan corak ini tidak bisa dilepaskan dari unsur-unsur yang melekat dari wilayah asal pembuatnya, serta dapat dipastikan tidak semua orang mengerti adanya sejarah panjang di balik motif batik tersebut. selain itu, makna filosofis yang terkandung dalam sebuah batik adalah berupa sebuah ungkapan hati dari pembuatnya ada harapan, doa, serta cita-cita.

Berdasarkan hasil penelitian pada bab sebelumnya, batik Pasedahan Suropati Kota Pasuruan, secara filosofis memiliki makna bahwa Untung Suropati adalah orang yang arif dan bijaksana, sehingga harapannya adalah orang yang memakai batik Pasedahan Suropati ini, memiliki sifat yang arif dan bijaksana pula, sebagaimana Untung Suropati. Sedangkan makna filosofis yang terdapat pada motif batik Pasedahan Suropati adalah sebagai berikut:

a. Motif Daun Suruh

Secara filosofis, motif Daun Suruh memiliki makna dari asal-usul nama Kota Pasuruan, yaitu Pa-suruh-an yang memiliki arti daun suruh (daun sirih). Pada zaman dahulu, di Kota Pasuruan tumbuh dengan subur tanaman suruh. Selain itu, daun suruh juga tidak bisa dilepaskan dari kehidupan sehari-hari masyarakat Pasuruan, mungkin juga di daerah lainnya. Daun suruh bersama dengan gambir, kapur, dan buah pinang dikunyah, yang mana mengunyah daun suruh ini adalah lambang persaudaraan dalam interaksi sosial.

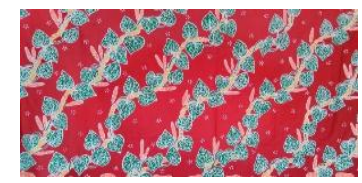

Gambar 9 Motif Daun Suruh b. Motif Burung Podang

Secara filosofis motif Burung Podang memiliki makna bahwa dalam sehari satu malam kewajiban umat Islam menjalankan sholat lima waktu sebanyak 17 rakaat, serta jumlah juz dalam Al-Qur'an sebanyak 30 juz. Makna filosofis ini dilihat dari jumlah helai bulu yang terdapat pada burung Phoenix, 17 helai pada ekor dan 30 helai pada sayap.

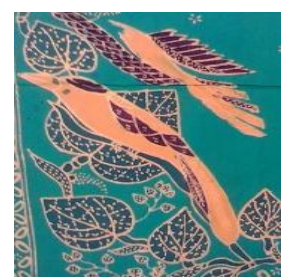

Gambar 10

Motif Burung Podang

c. Motif Gedung Harmoni

Motif Gedung Harmoni memiliki makna filosofis bahwa gedung Harmoni merupakan cagar budaya Kota Pasuruan. Gedung Harmoni merupakan salah satu bangunan tua yang terdapat di Jalan Pahlwan Nomor 21 Kota Pasuruan. Gedung ini dibangun pada tahun 1858 dan diresmikan pada tahun 1921. Gedung yang memiliki luas $750 \mathrm{~m}^{2}$ ini, hingga sekarang mengalami 4 kali alih fungsi, dan sekarang berfungsi sebagai gedung Yayasan Pendidikan Kejuruan Untung Suropati.

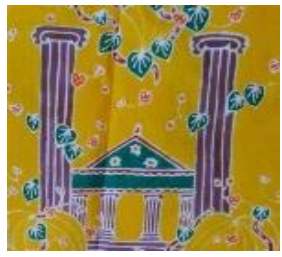

Gambar 11 Motif Gedung Harmoni

\section{d. Motif Tembikar}

Motif tembikar memiliki makna filosofis bahwa tembikar merupakan salah satu produk unggulan Kota Pasuruan, selain meubel Bukir. Hingga sekarang, kerajinan tembikar ini terpusat pada Kelurahan Randusari dan Sebani. Menurut cerita, dahulu banyak saudagar dari daerah lain bahkan dari Cina yang datang ke Pelabuhan Kota Pasuruan hanya untuk membeli 
tembikar khas Pasuruan, dan berdasarkan cerita inilah, tembikar dijadikan motif batik Pasedahan Suropati.

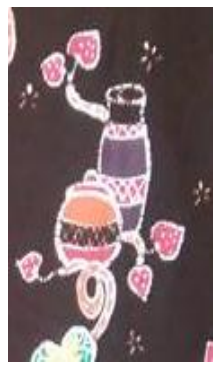

Gambar 12

Motif Tembikar

e. Motif Burung Phoenix

Motif Burung Phoenix pada batik Pasedahan Suropati secara filosofis memiliki makna bahwa masyarakat Kota Pasuruan terdiri atas beraneka ragam suku, ras, dan agama. Mulai dari suku Madura, Jawa, Arab, dan Cina.

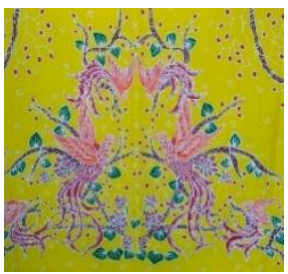

Gambar 13

Motif Burung Phoenix

\section{f. Motif Mangrove}

Motif Mangrove memiliki makna filosofis bahwa Kota Pasuruan merupakan kota pesisir, yang mana di sebelah utara berbatasan langsung dengan selat Madura. Pada bagian utara Kota Pasuruan inilah tumbuh dengan lebatnya pohon Mangrove. Hal inilah yang menjadikan pohon Mangrove dijadikan motif batik Pasedahan Suropati.

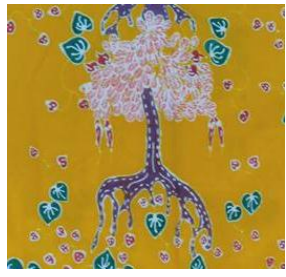

Gambar 14

Motif Mangrove

\section{Alternatif Penggunaan Motif Batik Pasedahan Suropati Dalam Pembelajaran Geometri Untuk Sekolah Dasar}

Berdasarkan konsep geometri untuk sekolah dasar pada motif batik Pasedahan Suropati yang dipaparkan pada Tabel 1, dengan demikian motif batik Pasedahan Suropati dapat dijadikan alternatif pembelajaran geometri sekolah dasar, seperti pada materi mengenal garis, mengenal sudut, serta mengenal bangun sederhana. Adapun langkah-langkah alternatif pembelajaran geometri untuk sekolah dasar dengan menggunakan batik Pasedahan Suropati adalah sebagai berikut:

a. Siswa bersama dengan guru melakukan tanya jawab terkait dengan batik Pasedahan Suropati

Tahukah Kamu?
Seragam apakah yang kamu pakai setiap hari kamis?
Motif apakah pada seragam itu?
Yach.. seragam batik itu bermotif daun suruh dan
burung podang.
Tahukah kamu kalau itu motif daun suruh dan
burung podang merupakan batik khas kota Pasuruan,
dan dinamakan batik pasedahan suropati?

b. Siswa diminta untuk membaca teks tentang batik Pasedahan Suropati

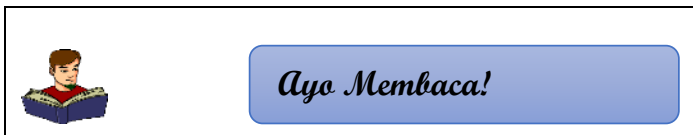

\section{BATIK PASEDAHAN SUROPATI}

Batik Pasedahan Suropati merupakan batik khas kota Pasuruan. Batik ini bermotifkan daun suruh dan burung podang. Pertama kali, motif batik pasedahan suropati ini dibuat oleh ibu Sri Kholifah, warga dari Bangil Kabupaten Pasuruan ketika mengikuti lomba desain batik khas daerah yang diadakan oleh Pemerintah Kota Pasuruan tahun 2003.

\section{Batik Pasedahan}

Suropati memiliki makna bahwa Suropati adalah orang yang bijak, harapannya adalah orang yang memakai batik Pasedahan Suropati ini memiliki hati yang bijak sebagaimana Suropati. Motif daun suruh diambil dari asal mula kota Pasuruan, yaitu Pa-suruh-an. Sedangkan burung podang merupakan burung yang pada zaman dahulu dengan mudah ditemukan di kota Pasuruan. Pada motif batik Pasedahan Suropati ini, burung podang tersebut memiliki 17 helai bulu pada ekor dan 30 helai pada sayapnya. Hal ini melambangkan bahwa dalam satu hari satu malam, 
orang Islam memiliki kewajiban sholat sebanyak 17 rakaat. Serta dalam Alquran terdapat 30 juz.

Batik Pasedahan Suropati merupakan kebudayaan asli kota Pasuruan yang patut untuk dilestarikan. Sebagai warga kota Pasuruan kita harus ikut bangga akan kebudayaan yang satu ini. Dan sebagai wujud bentuk pelestarian motif batik Pasedahan Suropati digunakan sebagai motif seragam batik yang kalian pakai setiap hari Kamis, serta seragam pegawai di lingkungan Pemerintah Kota Pasuruan.

c. Siswa mengamati motif batik Pasedahan Suropati yang lain

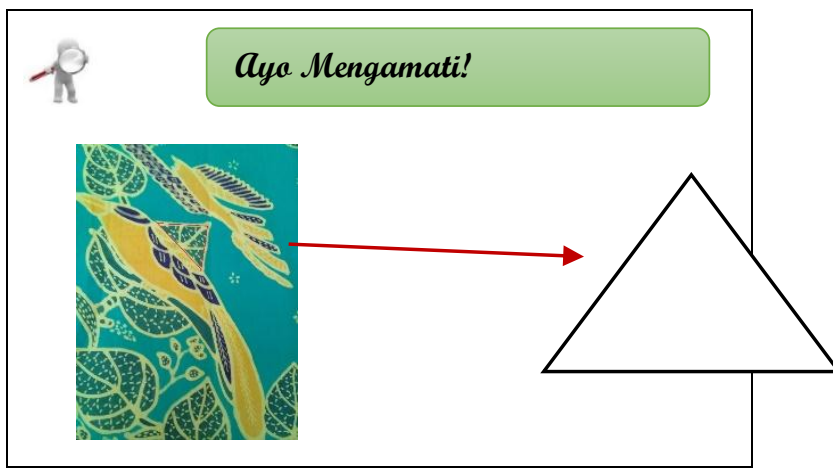

d. Siswa menganalisis bangun yang ada pada motif batik Pasedahan Suropati

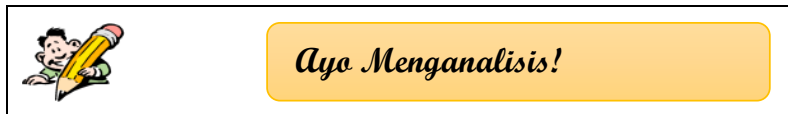

\section{Motif Gedung Harmoni}

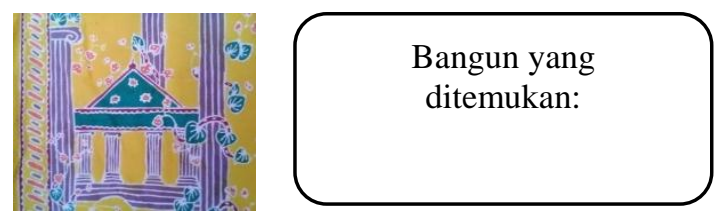

\section{Motif Daun Suruh}

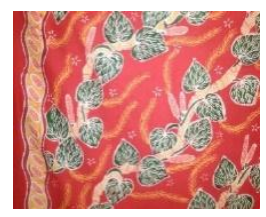

\section{Motif Burung Phoenix}

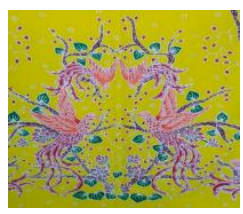

Bangun yang ditemukan:

\section{Motif Tembikar}
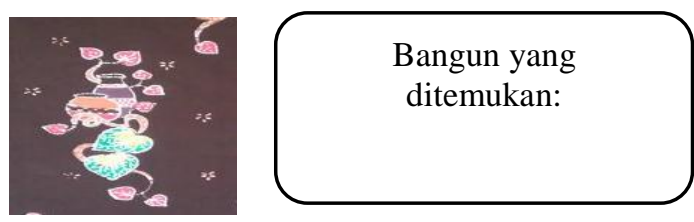

e. Siswa mempresentasikan hasil kerjanya

\section{SIMPULAN DAN SARAN}

Berdasarkan pembahasan pada sub bab sebelumnya, maka dapa disimpulkan bahwa konsep geometri untuk sekolah dasar yang terdapat pada motif batik Pasedahan Suropati adalah konsep titik, garis lurus, garis lengkung, garis zig-zag, garis tinggi, garis sejajar, sudut, segitiga, persegipanjang, oval, dan simetri lipat. Sedangkan, secara filosofis memiliki makna bahwa Untung Suropati adalah orang yang arif dan bijaksana, sehingga harapannya adalah orang yang memakai batik Pasedahan Suropati ini, memiliki sifat yang arif dan bijaksana pula, sebagaimana Untung Suropati, serta alternatif penggunaan motif batik Pasedahan Suropati dalam pembelajaran geometri di sekolah dasar dapat digunakan pada pengenalan garis, pengenalan sudut, dan pengenalan bangun datar sederhana. Adapun langkah-langkah alternatif pembelajaran tersebut adalah sebagai berikut: (1) siswa bersama guru melakukan tanya jawab terkait dengan batik Pasedahan Suropati untuk menggali pengetahuan awal siswa terkait dengan batik tersebut, (2) siswa membaca teks batik Pasedahan Suropati (sejarah dan makna filosofis batik Pasedahan Suropati), (3) siswa mengamati motif batik Pasedahan Suropati yang lainnya, serta pemetaan konsep geometri yang ada, (4) siswa menganalisis geometri yang ada pada motif batik Pasedahan Suropati yang lainnya, dan (5) siswa mempresentasikan hasil kerjanya.

Penelitian ini hanya terfokus pada satu subkajian objek saja, agar lebih efektif dan efisien dalam pembahasan, maka tidak menutup kemungkinan untuk dikembangkan pada materi matematika yang lainnya, dengan bentuk kebudayaan yang lain sesuai dengan kondisi tempat tinggal siswa.

\section{DAFTAR PUSTAKA}

Budiarto, Mega Teguh; Junaidi, Lalu Alwan; dan Hartono, Sugi. (2015). Ethnomathematics Sasak: Geometry Concepts In Community Life Banyumulek West 
Lombok. Paper of ICME in Semarang of State University at 2015, September 5.

Budiarto, Mega Teguh. (2016). Peran Matematika dan Pembelajarannya Dalam Mengembangkan Kearifan Budaya Lokal Mendukung Pendidikan Karakter Bangsa. Prosiding Seminar Nasional 2016 Program Studi Pendidikan Matematika Universitas Madura, Madura. Hal. 1-11.

Fitroh, Wahyu dan Hikmawati, Nurul. (2015). Identifikasi Pembelajaran Matematika Dalam Tradisi Melemang di Kabupaten Kerinci Provinsi Jambi. Prosiding Seminar Nasional Matematika dan Pendidikan UMS 2015. Surakarta. Hal. 334-344.

Kementerian Pendidikan dan Kebudayaan Republik Indonesia. (2016). Buku Siswa SD/MI Kelas IV Tema 1: Indahnya Kebersamaan. Jakarta: Kementerian Pendidikan dan Kebudayaan Republik Indonesia

Lipka, Jerry dan Andrew-Irkhe, Dora. (2009). Ethnomathematics Applied to Classroom in Alaska: Math in a Cultural Context. Paper at the NASGEM Ethnomathematics SIG at the 2009 Annual Meeting NCSM. p. 8-10.

Massarwe, K., Verner, I., dan Bshouty, D. (2013). Ethnomathematics and Multi-Cultural Education: Analysis and Contruction of Geometric Ornaments. Journal of Mathematics and Culture. ICEM 4 Focus Issue. 344-360.

Orey, Daniel Clarck dan Rosa, Milton. (2006). Ethnomathematics: Cultural Assertion and Challenges Towards Pedagogical Action. The Journal of Mathematics and Culture. 6 (1), 57-78.

Prawabati, Mega Nur. (2016). Etnomatematika Masyarakat Pengrajin Anyaman Rajapolah Kabupaten Tasikmalaya. Infinity Jurnal Ilmiah Program Studi Matematika STKIP Siliwangi Bandung. 5 (1), 25-31

Rosa, Milton dan Orey, Daniel Clark. (2011). Ethnomathemarics: The Cultural Aspect of Mathematics. Revista Latinoamericana de Etnomatematica. 4 (2), 32-54.

Spradley, James P. (1997). Metode Etnografi. (Misbah Zulfah Elizabeth, penerjemah). Yogyakarta: PT. Tiara Wacana Yogya.

Susanah dan Hartono. (2014). Geometri. Surabaya: Unesa University Press.

Walle, John A. Vann De. (2008). Matematika Sekolah Dasar dan Menengah Jilid 1 Edisi Keenam. (Suyono, Penerjemah). Jakarta: Erlangga.

Wibowo, Agus dan Gunawan. (2015). Pendidikan Karakter Berbasis Kearifan Lokal di Sekolah:
Konsep, Strategi, dan Implementasi. Yogyakarta: Pustaka Pelajar.

Wulandari, Ari. (2011). Batik Nusantara: Makna Filosofis, Cara Pembuatan dan Industri Batik. Yogyakarta: CV. Andi Offset (Andi). 